\title{
Leaf traits interact with management and water table to modulate ecosystem properties in fen peatlands
}

\author{
Fabio Carvalho 1 - Kerry A. Brown • \\ Martyn P. Waller • Arnoud Boom
}

Received: 29 November 2018 / Accepted: 1 May 2019/Published online: 27 May 2019

(C) The Author(s) 2019

\begin{abstract}
Aims Trade-offs between slow and fast nutrient turnover rates among plants may affect soil properties and biomass production. We examined how plant traits interact with abiotic variables to modulate ecosystem properties (soil $\mathrm{C}$, soil $\mathrm{C} / \mathrm{N}$ ratio, aboveground biomass) in peatlands.

Methods We determined the interacting effects of abiotic variables (vegetation management, water table height) and leaf traits (specific leaf area, leaf drymatter content, leaf $\mathrm{C} / \mathrm{N}$ ratio) on ecosystem properties
\end{abstract}

Responsible Editor: Luca Bragazza.

Electronic supplementary material The online version of this article (https://doi.org/10.1007/s11104-019-04126-6) contains supplementary material, which is available to authorized users.

F. Carvalho $(\bowtie) \cdot$ K. A. Brown $\cdot$ M. P. Waller

Department of Geography and Geology, Kingston University London, Penrhyn Road, Kingston upon Thames, Surrey KT1 2EE, UK

e-mail: fabiocgs@yahoo.com

\section{K. A. Brown}

e-mail: k.brown@kingston.ac.uk

M. P. Waller

e-mail: martynwaller58@gmail.com

\section{A. Boom}

School of Geography, Geology and the Environment, University of Leicester, Leicester LE1 7RH, UK

e-mail: ab269@leicester.ac.uk in two lowland fens in East Anglia, UK using structural equation modelling.

Results Our models explained between 21\% and 95\% of the variability in ecosystem properties. Leaf traits directly influenced soil nutrient content and plant biomass and mediated the effects of abiotic variables on ecosystem properties. Abiotic variables exerted larger effects on ecosystem properties among herbaceous communities, but leaf traits were equally important when modelling all communities in combination.

Conclusions The expected trade-offs between exploitative and conservative life strategies among species scaled-up to changes in soil properties and biomass production, even in fen habitats where abiotic variables play an important role through marked seasonal variations. Our findings suggest an important role of leaf economics in the functioning of fens, but their effects on ecosystems may be highly dependent on local conditions.

Keywords Aboveground biomass · Leaf economics spectrum $\cdot$ Path analysis $\cdot$ Soil C $\cdot$ Structural equation modelling
Abbreviations
AGB Aboveground biomass
CFI Comparative fit index
CWM Community weighted-mean
LDMC Leaf dry-matter content
LES Leaf economics spectrum
LLS Leaf lifespan
NFI Normed fit index 
NMDS Non-metric multidimensional scaling

RMSEA Root mean square error of approximation

SEM Structural equation modelling

SLA Specific leaf area

\section{Introduction}

Determining the response of ecosystem properties to changing environmental conditions in peatlands is becoming increasingly important, particularly for informing conservation policies for ecosystem management (Mainstone et al. 2016). However, changing environmental conditions and anthropogenic pressures have adversely affected ecosystem properties and services in wet habitats in the UK (Mainstone et al. 2016) and elsewhere (Mitsch and Gosselink 2015).

Despite some evidence that changes in plant trait composition can alter ecosystem properties in peatlands (Ward et al. 2009), abiotic variables have been typically considered the primary drivers of ecosystem properties in wet environments (Keddy 2010; Mitsch and Gosselink 2015). This may be especially true for water table height (Bellisario et al. 1998) and vegetation management (Minden et al. 2016). Wet conditions may adversely affect plant productivity and aboveground biomass (AGB) owing to a decrease of the oxic zone that hinders the release of soil nutrients by mineralization and decreases the space for plant roots (Morris et al. 2011). However, it can positively influence soil C content due to slower organic matter turnover under anaerobic conditions (Mitsch and Gosselink 2015). Dry conditions can also affect plant productivity and may be dependent on the onset, length and severity of drought periods (Lund et al. 2012). Vegetation management (e.g., mowing) can affect soil nutrient content (Worrall et al. 2011) and AGB production (Minden et al. 2016), partly due to changes in the trait composition of plant communities (Vinther and Hald 2000). Mowing was formerly widely practiced in fen peatlands throughout Europe to produce both fodder and raw materials for a variety of purposes such as roof thatching (Charman 2002). Today, mowing is generally undertaken for conservation management in open herbaceous fens to prevent scrub encroachment and succession into fen carr (Wheeler and Shaw 1995), which results in plant communities with distinct functional identity that is dependent on the intensity of mowing (Vinther and Hald
2000). In this context, changes in community-level traits driven by management may compound the effects of other abiotic variables such as water table height and play an important role in ecosystem properties.

Leaf traits like specific leaf area (SLA), leaf drymatter content (LDMC) and leaf $\mathrm{C} / \mathrm{N}$ ratio are commonly related to a plant's photosynthetic and nutrient turnover rates (Niinemets 1999; Westoby et al. 2002; Wright et al. 2004) and are known to mediate changes in soil nutrient content (Lavorel and Garnier 2002). Species with high leaf area-to-dry-mass invested in leaf tissue are more efficient in capturing light and fixing carbon than those with opposite characteristics that result in slower carbon gain but longer leaf lifespans with more durable leaf tissue (Niinemets and Sack 2006). This variability in species' carbon uptake and leaf quality represents a continuum within the leaf economics spectrum (LES; Wright et al. 2004) that helps drive changes in ecosystem properties (Donovan et al. 2014; Minden and Kleyer 2011). Leaf traits are thus thought to be involved in a response-effect framework in which the functional trait structure of a community is driven by plant responses to external factors via response traits, while changes in ecosystem properties due to environmental change may be mediated by plants via effect traits (Lavorel and Garnier 2002).

The aim of this study was to quantify the size and direction (positive or negative) of direct and indirect effects of abiotic variables and leaf traits on ecosystem properties in herbaceous and wooded lowland fen peatlands subject to different management intensities and changes in water table height. We summarized the relationships between different ecosystem components (Fig. 1) to test our a priori knowledge against dependence models using path analyses and structural equation modelling (e.g., Grace and Pugesek 1997). We considered soil properties (soil C content and soil C/N ratio of the top $10 \mathrm{~cm}$ of soil) and AGB as the ecosystem properties in our analysis. We did not expect controls on ecosystem properties in wetlands to be dichotomous, nor modulated by changes in plant traits caused by abiotic variables (e.g., management) alone, but rather influenced by both biotic and abiotic variables to varying degrees. We hypothesized that abiotic variables would exert direct effects on ecosystem properties, as well as indirect effects mediated through leaf traits (Fig. 1). Specifically, we hypothesized that intense management in fens may favor conservative species (i.e., thickleaved species well-adapted to disturbance) with low 

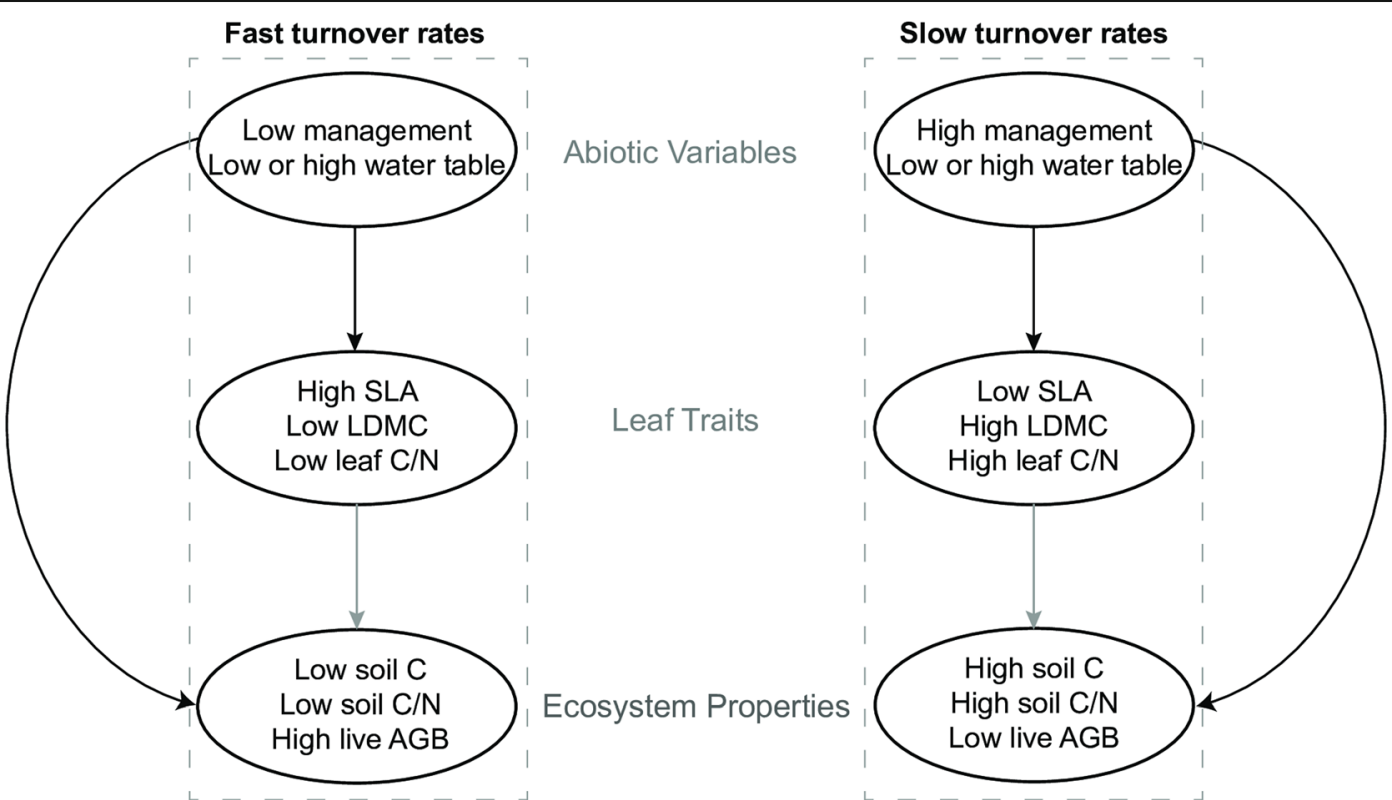

Fig. 1 Conceptual diagram depicting the opposite effects of fast (left side) vs. slow (right side) turnover rates of abiotic variables and leaf traits on ecosystem properties of managed lowland fens. Abiotic variables can exert direct effects on ecosystem properties

SLA but high LDMC and leaf $\mathrm{C} / \mathrm{N}$ ratio (Carvalho 2017; Kołos and Banaszuk 2013), resulting in high soil $\mathrm{C}$ content in the top soil and low live biomass through lower primary productivity and organic matter turnover rates (Fig. 1; Lavorel and Grigulis 2012). Alternatively, we hypothesized that the absence of regular management may result in plant communities dominated by exploitative strategies (i.e., high photosynthetic rates facilitated by thin, short-lived leaves) that result in fast turnover rates due to relatively high nutrient mineralization (Fig. 1). We expected wetter conditions to generally result in higher soil $\mathrm{C}$ content under anaerobic decomposition (Musarika et al. 2017). However, changes caused by the variability in soil saturation are harder to predict given the diverse responses of ecosystems and plant communities to waterlogging (de Deyn et al. 2008; Minden and Kleyer 2011; Updegraff et al. 2001).

\section{Materials and methods}

Study sites

Upton and Woodwalton are two lowland fen peatlands in East Anglia, UK containing woody and herbaceous vegetation (Online Resource 1: Fig. S1.1). Lowland fens (curved arrows) and leaf traits (black arrows). Leaf traits can have a direct influence on ecosystem properties or act as mediating the effects of abiotic variables (greyed arrows). See Table 2 for abbreviations

occupy the seasonally and periodically flooded habitat zone between swamps and dry land in hydroseral succession and have marked abiotic gradients (e.g., water level, soil fertility, management) that exert strong controls on their ecology (Wheeler and Proctor 2000). The herbaceous communities at both sites (with the exception of the unmown glades at Woodwalton) are regularly mown to prevent succession into fen carr and maintain characteristic species of open fens (Table 1). Upton Broad $\left(52^{\circ} 40^{\prime} \mathrm{N} 1^{\circ} 31^{\prime} \mathrm{E}\right)$ is a 105 -ha nature reserve receiving surface water from a small local catchment dominated by drained pasture and arable land (Bennion et al. 2001). The tall-herbaceous fens include reedswamp and Cladium and Juncus fens (dominated respectively by Phragmites australis, Cladium mariscus and Juncus subnodulosus) that are mown on a seven- to eight-year rotation, with cuttings removed after mowing. The fen carr communities comprise unmanaged and well-developed alder-dominated (Alnus glutinosa with Fraxinus excelsior) and mixed woodland (with Betula pubescens, Quercus robur and other species).

Woodwalton Fen $\left(52^{\circ} 26^{\prime} \mathrm{N} 0^{\circ} 11^{\prime} \mathrm{W}\right)$ is a 205 -ha rectangular block of relict peatland isolated from the surrounding arable farmland by raised flood banks. The alder carr (A. glutinosa, B. pubescens) and the adjacent unmown glades (Calamagrostis canescens, 


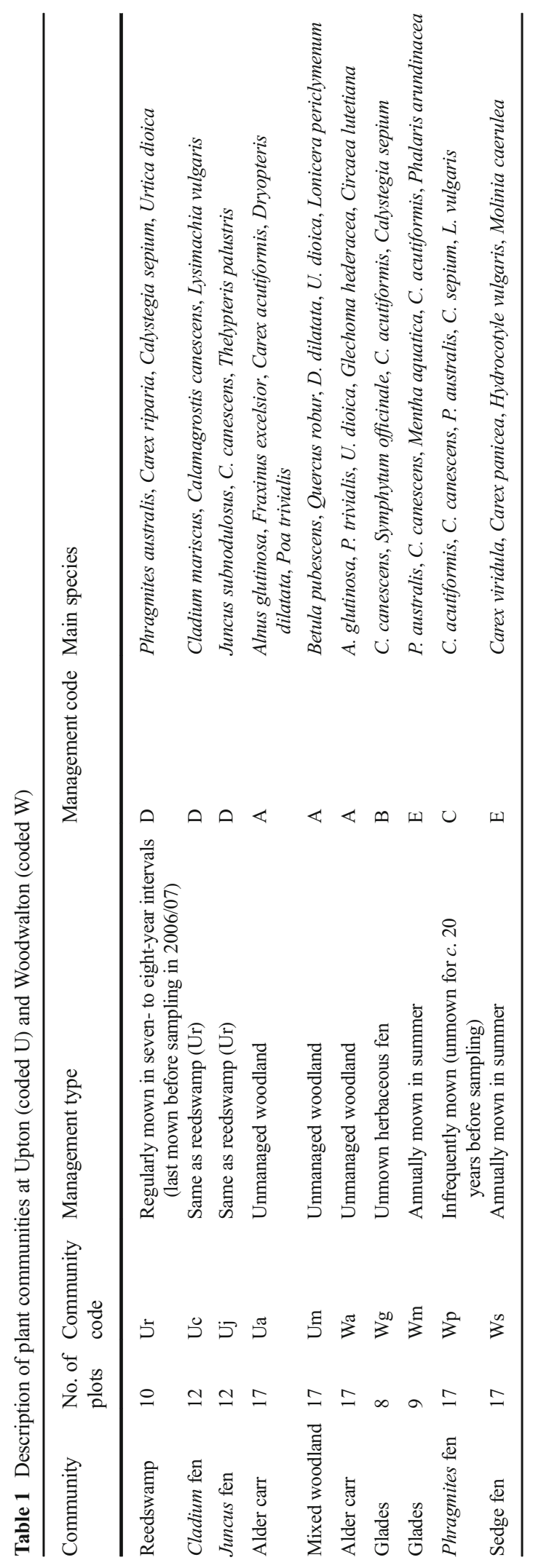

P. australis) are unmanaged, while the mown glades (C. canescens, Carex acutiformis) and sedge fen (Carex viridula, Carex panicea) are mown annually. The Phragmites fen ( $P$. australis, C. acutiformis) is mown on a twenty-year rotation. Cuttings are removed from all managed herbaceous fens after mowing.

Mosses were scarce at both sites with $<4 \%$ cover at the community level (see below for abundance estimation methods), the exception being the alder carr at Upton ( $8.2 \%$ cover). Kindbergia praelonga was the most frequently recorded species, while other common fen taxa like Calliergonella cuspidata, Plagiomnium undulatum, Rhytidiadelphus squarrosus and Brachythecium rutabulum were also present. See Table 1 and Waller et al. (2017) for further details of the sites.

\section{Vegetation data}

Vegetation surveys took place in summers 2013 and 2014 at Upton and Woodwalton, respectively within 136 circular sampling plots of 2-m radius spaced 6-m apart along transect lines (Online Resource 1: Fig. S1.1). Transects were stratified by plant communities to ensure a broad spatial representation of both fen carr and herbaceous fens. In order to record the spring ephemerals and perennials present, surveys were conducted in late May in the woodlands and between July and September in the open herbaceous communities. Plant abundance was determined on a first 'hit' basis for each species using a point quadrat method by dropping a plumb-bob into the center of five rings of equal area, spaced at 0.45 , $1.08,1.41,1.67$ and $1.89 \mathrm{~m}$ from the centre of the plot. These distances ensured equal weight to any point within the survey plot. If more than one species was touched by the pin, each species was recorded as one 'hit'. Plotlevel (or community-level) relative abundances were calculated by scaling species counts to the total count of a given sampling plot (or community). Species not 'hit' during the field surveys, but present within the 2-m circle area, were also recorded (but not included in abundance estimations or any analysis presented here since they did not have 'counts'). A total of 130 vascular plant species were present across the two fens, of which 103 were 'hit' during the surveys.

Leaves from vascular plants were collected from sunexposed healthy-looking adult individuals, totaling 64 species that represented $98 \%$ of total species cover across Upton and Woodwalton (Online Resource 2). 
Leaf traits were determined following standardized protocols (Pérez-Harguindeguy et al. 2013). Leaf samples were kept in moistened bags at under $4{ }^{\circ} \mathrm{C}$ for up to $72 \mathrm{~h}$ prior to fresh leaf mass and area measurements. Leaf lamina and petiole were used to determine fresh leaf area with a leaf area meter (LI-COR LI3000C), while leaf dry mass was computed after oven drying for $72 \mathrm{~h}$ at $70{ }^{\circ} \mathrm{C}$. Oven-dried samples (leaf lamina only) were powdered by grinding and weighed to $5 \pm 0.2 \mathrm{~g}$. They were analyzed for leaf $\mathrm{C}$ and $\mathrm{N}$ content (\%) via dry combustion methods using a Sercon ANCA elemental analyzer, coupled to a Sercon 20-20 isotope ratio monitoring mass spectrometer. Measurements were carried out in triplicates of each sample, resulting in precisions of $\leq 0.5 \%$. Outlier replicates were excluded from samples with lower levels of precision when necessary.

In order to reduce the dimensionality and represent the main trends in the vegetation data, we used the 64 species with trait and abundance data to perform unconstrained vegetation ordination using non-metric multidimensional scaling (NMDS) with the function metaMDS in the vegan package (Oksanen et al. 2019) in $\mathrm{R}$ ( $\mathrm{R}$ Development Core Team 2018). metaMDS uses the Bray-Curtis dissimilarity index by default and tries to find the best possible solution by using random starts and iterations to minimize the stress function (scaled between 0 and 1 ), which estimates how far the distances between objects in a $k$ dimension configuration are from being monotonic to the observed distances (Borcard et al. 2011). We also tested the strength of the association between NMDS ordination and the abiotic variables (management and water table height) using the function envfit in vegan (Oksanen et al. 2019).

We computed plot-level community weighted means (CWM) representing the mean trait value per unit of biomass in a community (Violle et al. 2007). CWMs are suitable for studying the relationships between traits and the environment since they emphasize the traits of the most dominant species with higher performance (Garnier et al. 2016). CWMs were calculated by transforming species counts into relative abundances by scaling them to the total count of a given sampling plot:

$$
C W M=\sum_{i=1}^{S} p_{i} x_{i}
$$

where $p_{i}$ is the relative abundance of the $i$-th species in a given plot and $x_{i}$ its mean trait value (Dainese et al. 2015). The distribution of plot-level CWMs within each plant community at Upton and Woodwalton are shown in Fig. 2 (panels a to c).

\section{Soil data}

Soil sampling took place at Upton and Woodwalton in Autumn 2012 and 2013, respectively within the same sampling plots used for the vegetation surveys. Four samples were collected from each plot using a Russian auger to a depth of $10 \mathrm{~cm}$ and spaced at $50 \mathrm{~cm}$ distances marking the corners of a $0.25 \mathrm{~m}^{2}$ quadrat established at $90^{\circ}$ angles to the transect line. Plant litter was removed from the top soil and samples were split longitudinally and homogenized at the plot level. Approximately one third of each homogenized sample was oven-dried at $105^{\circ} \mathrm{C}$ until constant mass was reached. The remaining two thirds of each sample were air-dried for $72 \mathrm{~h}$, gently ground with a porcelain mortar and pestle and sieved in an electric shaker for 10 min with graded sieves of 710,500 and $150 \mu \mathrm{m}$. Soil carbon and nitrogen content $(\%)$ were determined for the airdried samples using the same dry combustion methods described above, resulting in precisions within $0.1 \%$ for soil $\mathrm{N}$ and $1.6 \%$ for soil $\mathrm{C}$. Additionally, pollen analysis was performed on one randomly chosen soil core from each plant community to ensure the upper $10 \mathrm{~cm}$ of sediment was derived from the contemporary vegetation (Online Resource 3: Figs. S3.1 and S3.2).

Water table data

Long-term monthly dipwell data for Upton and Woodwalton were provided by the Environment Agency and Natural England, respectively. Data from the dipwells were in close proximity to the surveyed plant communities and their relative heights could be related through levelling to the field locations and to the UK national height system. Sample plot elevations were averaged for the estimation of the height of the water table. Continuous monthly dipwell data from the previous five years before soil sampling took place (20072012 for Upton and 2008-2013 for Woodwalton) were averaged to provide a mean seasonal water table height for each plot for the summer (April-September) and winter (October-March) months. 

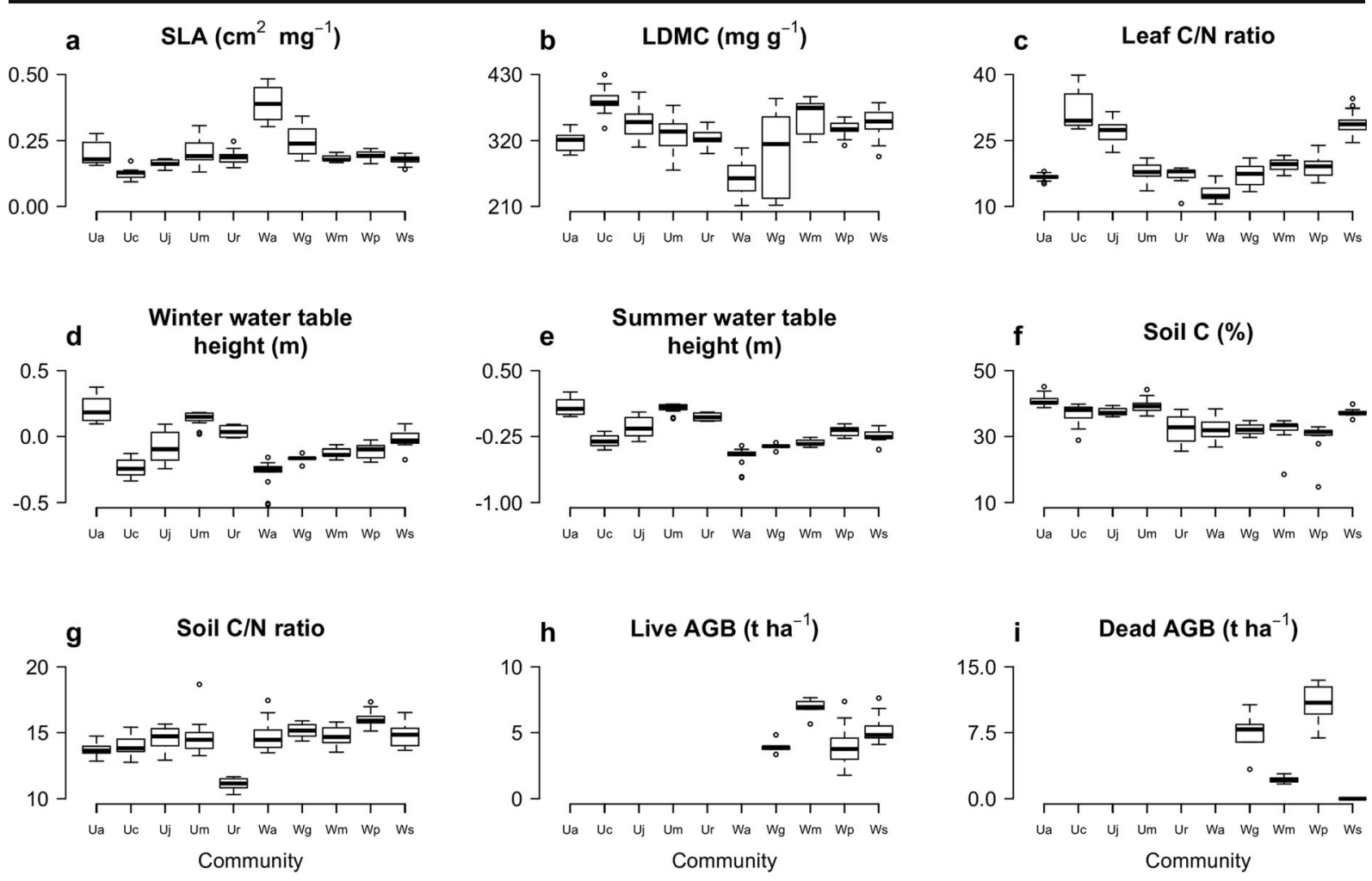

Fig. 2 Data distribution of the leaf traits (panels a to c), abiotic variables (panels $\mathrm{d}$ and e) and ecosystem properties (panels $\mathrm{f}$ to i) used in the path models. AGB data (panels h and i) were only

available for the herbaceous communities at Woodwalton (Wg, Wm, Wp and Ws). See Table 1 for community codes and Table 2 for abbreviations

Aboveground biomass (AGB) data

AGB were harvested from the herbaceous communities in Woodwalton Fen in late summer 2014. Ten onesquare-meter plots spaced $6 \mathrm{~m}$ apart were harvested following the transect line at each of the four herbdominated communities that comprised 51 sampling plots. Plant material were clipped at ground level and weighed separately as live and dead standing AGB after oven-drying at $70{ }^{\circ} \mathrm{C}$ for $72 \mathrm{~h}$. Since biomass were not harvested at Upton, AGB were modelled as an ecosystem property in the model that included only the herbaceous communities at Woodwalton (51 plots).

Path analyses and structural equation modelling (SEM)

SEM is useful to determine direct effects of predictor variables on measured response data, as well as indirect effects through mediating variables (Sokal and Rohlf 2012). Path models use correlation coefficients and regression analyses to estimate cause-and-effect relationships among multiple variables by using straight, single-headed arrows that denote standardized partial regression coefficients of direct effects (Schumacker and Lomax 2010). Path analysis starts with an initial conceptual model based on a priori knowledge of the functioning of the system, which is then tested against the covariance matrix of the observed data (Maruyama 1998). The model is evaluated by a chi-square $\left(\chi^{2}\right)$ test of fit, in which a significant $p$ value $(p<0.05)$ indicates that the covariance structure of the data differs significantly from that of the hypothesized model. A good fit of the hypothesized model to the data will thus result in a low $\chi^{2} / d f$ ratio, and should ideally be $<2$ (Byrne 2010). The NFI (normed fit index) and CFI (comparative fit index) are other measures commonly used to evaluate model fit and indicate the proportion of improvement of the overall fit of the model relative to the independence model (where all correlations among variables are zero). Values close to 1 are generally considered to indicate a good fit, and should ideally be $>0.9$ (Byrne 2010). The RMSEA (root mean square error of approximation) index evaluates the extent to which a model fails to fit the data per degree of freedom, and tends to favor more 
Table 2 Abiotic variables, leaf traits and ecosystem properties used in the path models, with mean values and standard deviations $(s)$ shown separately for Upton and Woodwalton. The Plots column refers to the number of plots for which data were available

\begin{tabular}{|c|c|c|c|c|c|c|c|}
\hline & \multirow[t]{2}{*}{ Abbreviation } & \multirow[t]{2}{*}{ Unit } & \multirow[t]{2}{*}{ Plots } & \multicolumn{2}{|l|}{ Upton } & \multicolumn{2}{|c|}{ Woodwalton } \\
\hline & & & & Mean & $s$ & Mean & $s$ \\
\hline \multicolumn{8}{|l|}{ Abiotic variables } \\
\hline Management & Man & $\ddagger$ & 136 & - & - & - & - \\
\hline Water table height (summer) $\dagger$ & WTs & $\mathrm{m}$ & 136 & -0.04 & 0.16 & -0.31 & 0.13 \\
\hline Water table height (winter) $\dagger$ & WTw & $\mathrm{m}$ & 136 & 0.04 & 0.18 & -0.13 & 0.11 \\
\hline \multicolumn{8}{|l|}{ Leaf traits } \\
\hline Specific leaf area & SLA & $\mathrm{cm}^{2} \mathrm{mg}^{-1}$ & 136 & 0.18 & 0.04 & 0.24 & 0.10 \\
\hline Leaf dry-matter content & LDMC & $\mathrm{mg} \mathrm{g}^{-1}$ & 136 & 338.90 & 32.22 & 319.58 & 51.46 \\
\hline Leaf $\mathrm{C} / \mathrm{N}$ ratio & Leaf $\mathrm{C} / \mathrm{N}$ & ratio & 136 & 21.61 & 6.65 & 19.90 & 6.23 \\
\hline \multicolumn{8}{|l|}{ Ecosystem properties } \\
\hline Soil C & Soil C & $\%$ & 136 & 37.93 & 3.76 & 32.92 & 4.11 \\
\hline Soil $\mathrm{C} / \mathrm{N}$ ratio & Soil C/N & ratio & 136 & 13.75 & 1.42 & 15.11 & 0.95 \\
\hline Aboveground biomass (live) & AGBlive & $\mathrm{t} \mathrm{ha}^{-1}$ & 51 & - & - & 4.89 & 1.58 \\
\hline Aboveground biomass (dead) & AGBdead & $\mathrm{t} \mathrm{ha}^{-1}$ & 51 & - & - & 5.21 & 5.02 \\
\hline
\end{tabular}

$\dagger$ Water table height was computed as the distance (in meters) of the water table to the surface of each sampling plot using dipwell data from the five years preceding soil sampling

\$ Management was a categorical variable coded from A to E (see Table 1)

complex models (Browne and Cudeck 1993). RMSEA indicates a poor fit if it is $>0.1$, but should ideally be $<0.05$ (Byrne 2010). Therefore, good fitting models have relatively low $\chi^{2}, p>0.05, \chi^{2} / d f<2$, NFI and CFI $>0.9$ and RMSEA $<0.05$ (or at least $<0.1$ ).
The vegetation and abiotic data used in the path analyses are summarized in Table 2 (arranged by site) and Table 3 (arranged by management type), with data distribution across the different communities at Upton and Woodwalton shown in Fig. 2. Two models were

Table 3 Means and standard deviations $( \pm 1)$ of abiotic variables, leaf traits and ecosystem properties for each type of management

\begin{tabular}{|c|c|c|c|c|c|}
\hline & $\begin{array}{l}\text { Woodlands } \\
(n=51)\end{array}$ & $\begin{array}{l}\text { Unmown glades } \\
(n=8)\end{array}$ & $\begin{array}{l}\text { Infrequently mown } \\
(n=17)\end{array}$ & $\begin{array}{l}\text { Regularly mown } \\
(n=34)\end{array}$ & $\begin{array}{l}\text { Annually mown } \\
(n=26)\end{array}$ \\
\hline \multicolumn{6}{|l|}{ Abiotic variables } \\
\hline WTs (m) & $-0.1 \pm 0.27$ & $-0.36 \pm 0.03$ & $-0.19 \pm 0.05$ & $-0.16 \pm 0.14$ & $-0.27 \pm 0.07$ \\
\hline WTw (m) & $0.02 \pm 0.23$ & $-0.17 \pm 0.03$ & $-0.11 \pm 0.05$ & $-0.1 \pm 0.14$ & $-0.05 \pm 0.08$ \\
\hline \multicolumn{6}{|l|}{ Leaf traits } \\
\hline $\operatorname{SLA}\left(\mathrm{cm}^{2} \mathrm{mg}^{-1}\right)$ & $0.27 \pm 0.1$ & $0.25 \pm 0.06$ & $0.19 \pm 0.02$ & $0.16 \pm 0.03$ & $0.18 \pm 0.02$ \\
\hline LDMC $\left(\mathrm{mg} \mathrm{g}^{-1}\right)$ & $300.91 \pm 39.71$ & $299.56 \pm 72.53$ & $340.2 \pm 12.64$ & $354.84 \pm 32.77$ & $353.29 \pm 27.33$ \\
\hline Leaf $\mathrm{C} / \mathrm{N}$ ratio & $15.87 \pm 2.67$ & $17.17 \pm 2.76$ & $19.21 \pm 2.34$ & $25.91 \pm 7.01$ & $25.69 \pm 5.09$ \\
\hline \multicolumn{6}{|l|}{ Ecosystem properties } \\
\hline Soil C (\%) & $37.58 \pm 4.42$ & $32.15 \pm 1.74$ & $30.28 \pm 4.18$ & $35.7 \pm 3.79$ & $35.2 \pm 4.04$ \\
\hline Soil $\mathrm{C} / \mathrm{N}$ ratio & $14.37 \pm 1.09$ & $15.16 \pm 0.53$ & $16 \pm 0.58$ & $13.33 \pm 1.62$ & $14.74 \pm 0.79$ \\
\hline Live AGB $\left(\mathrm{t} \mathrm{ha}^{-1}\right)$ & - & $3.95 \pm 0.55$ & $4.05 \pm 1.64$ & - & $5.77 \pm 1.29$ \\
\hline Dead AGB $\left(\mathrm{t} \mathrm{ha}^{-1}\right)$ & - & $7.34 \pm 2.72$ & $10.87 \pm 2.05$ & - & $0.72 \pm 1.08$ \\
\hline
\end{tabular}

Numbers within brackets in column headers are sample sizes. See Table 1 for a description of the management types and Table 2 for abbreviations 
built to consider all plots in combination (fen model, 136 plots) and the herbaceous communities separately (herb fen model, 51 plots), given AGB data were only available for the herbaceous sites in Woodwalton. Three levels of ecosystem components were recognised: abiotic variables, leaf traits and ecosystem properties. Abiotic variables were modelled as independent variables having direct effects on leaf traits and ecosystem properties, as well as exerting indirect effects through the mediating effects of leaf traits on ecosystem properties. Leaf traits were thus modelled as both response and effect traits. The relationship between leaf traits were also included in the models to test the trade-off between competing resource-use strategies (i.e., conservative vs. exploitative strategies).

We modified the hypothesized full models (i.e., models depicting all path coefficients between predictor and response variables) to reduced models to improve their overall fit by removing non-significant $(p>0.05)$ standardized partial regression coefficients. Akaike's Information Criteria (AIC) were used to compare the full and reduced models, with the model presenting the lowest AIC value considered as the best overall fit to the observed data structure. We used the convention adopted by Lavorel and Grigulis (2012) and considered regression coefficients $>0.8$ as having a large effect, between 0.2 and 0.5 moderate and $<0.2$ small. Path analysis and SEM were implemented using IBM SPSS Amos 24.0.0 (Amos Development Corporation, Spring House, PA, US).

\section{Results}

Variation in leaf traits and abiotic variables

Plant communities across Upton and Woodwalton differed in terms of mean leaf trait composition (Fig. 2a-c). The alder carr plots in Woodwalton showed relatively high SLA values (Fig. 2a), while the Cladium and Juncus fens in Upton had the thickest, most C-rich leaves (Fig. 2b, c). The Upton sites were somewhat wetter than the Woodwalton ones, particularly the woodlands and the reedswamp (Fig. 2d, e). Variability in soil C was generally low across both fens (Fig. 2f), though soil $\mathrm{C} / \mathrm{N}$ ratio was noticeably lower at the reedswamp in Upton (Fig. 2g). Overall, the most intensely mown herb fens in Woodwalton had relatively high live AGB and low dead AGB compared to the lesser managed sites (Fig. 2h, i).
Variation in vegetation composition

The results of NMDS ordination are presented in Fig. 3 (stress $=0.175, k=2,20$ iterations). Management and NMDS site scores were strongly associated $\left(r^{2}=0.81\right.$, $p<0.001,999$ permutations $)$, though summer $\left(r^{2}=0.15\right.$, $p<0.001,999$ permutations $)$ and winter $\left(r^{2}=0.11\right.$, $p<0.001,999$ permutations) water table height were only weakly associated with NMDS scores. There was a clear separation between the unmanaged woodlands (management category A) and the herbaceous fen communities (Fig. 3a, c). Carex viridula, Carex panicea, Hydrocotyle vulgaris and Molinia caerulea were some of the most abundant species in the annually mown (category E) sites (Fig. 3b, d; not all species are labelled). The alder carr and mixed woodland in Upton were associated with wetter conditions (Fig. 3a, b), with Salix cinerea an important understory species. There was a large degree of overlap between the unmown, infrequently and regularly mown herb fens (management categories B, C and D), with Juncus subnodulosus, Cladium mariscus, Filipendula ulmaria and Lysimachia vulgaris some of the most abundant species in the mid-range of the management gradient (Fig. 3d). Phragmites australis and Calamagrostis canescens were relatively abundant throughout the herb fen communities (Fig. 3d).

Effects of abiotic variables and leaf traits on ecosystem properties

The reduced fen model (Fig. 4a) showed a better fit to the covariance structure of the observed data than the full model $\left(\mathrm{AIC}_{\text {reduced }}=75.66, \mathrm{AIC}_{\text {full }}=88\right)$ and presented good model fit parameters $\left(\chi^{2}=7.66, d f=10\right.$, $p=0.66, \chi^{2} / d f=0.77, \mathrm{NFI}=0.99, \mathrm{CFI}=1.0, \mathrm{RMSEA}$ $<0.001)$. Retaining only the significant standardized partial regression coefficients $(p<0.05)$ in the herb fen model (Fig. 4b) also improved its overall fit $\left(\mathrm{AIC}_{\text {reduced }}=89.44, \mathrm{AIC}_{\text {full }}=108\right)$ and model parameters $\left(\chi^{2}=9.44, d f=14, p=0.8, \chi^{2} / d f=0.67, \mathrm{NFI}=\right.$ $0.97, \mathrm{CFI}=1.0, \mathrm{RMSEA}<0.001)$.

The combined effects of abiotic variables and leaf traits explained $43 \%$ of the variance in soil $\mathrm{C}$ and $21 \%$ of the variability in soil $\mathrm{C} / \mathrm{N}$ ratio in the fen model (Fig. 4a). Leaf traits showed moderate to large responses to changes in vegetation management and water table height (see $r^{2}$ values in Fig. 4a). Increasing mowing 

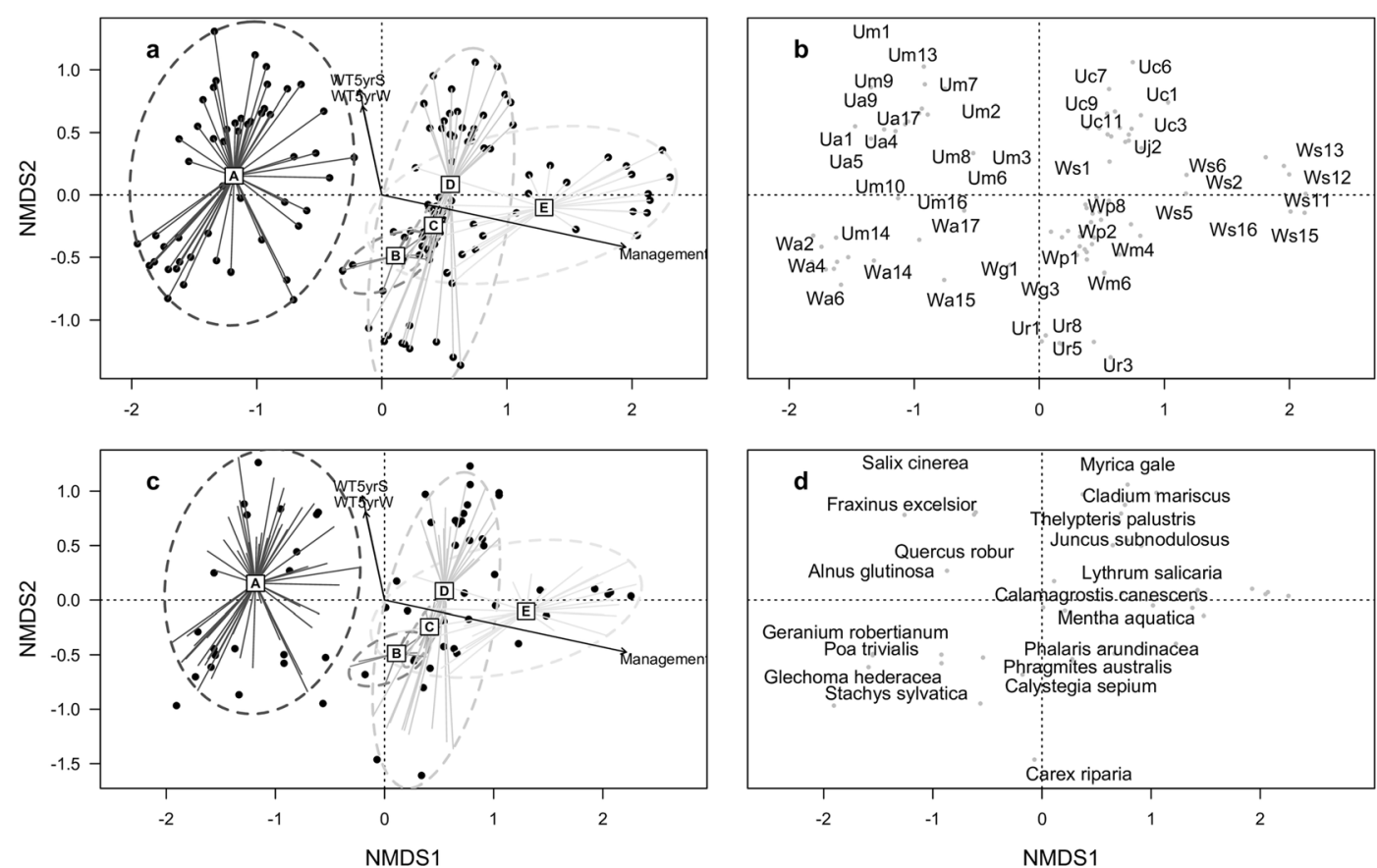

Fig. 3 Non-metric multidimensional scaling (NMDS) biplots using abundance data for the 64 species with trait measurements. Site coordinates are shown in the top row (black dots in panel a and grey dots in panel b) and species coordinates are shown in the bottom row (black dots in panel c and grey dots in panel d). Species were added using weighted averages. Only a selection of plots (panel b) and the most abundant species (panel d) are labelled for clarity. Plant community codes in panel $b$ are as shown in

intensity resulted in lower SLA but higher leaf $\mathrm{C} / \mathrm{N}$ ratio, while higher soil saturation in winter was linked to higher SLA (Fig. 4a, Table 4). SLA and LDMC decreased as summer soil saturation increased (Fig. 4a, Table 4). Sites that were wetter in winter and less frequently managed were associated with higher soil $\mathrm{C}$ and soil $\mathrm{C} / \mathrm{N}$ ratio (Fig. 4a, Table 4). However, increasing soil saturation in summer led to lower soil $\mathrm{C} / \mathrm{N}$ ratio (Fig. 4a, Table 4). Soil C increased with increasing leaf $\mathrm{C} / \mathrm{N}$ ratio, but soil $\mathrm{C} / \mathrm{N}$ ratio decreased with increasing SLA (Fig. 4a, Table 4). Greater leaf C/N ratio was linked to decreased SLA, while higher SLA was associated with lower LDMC (Fig. 4a, Table 4). There were no indirect effects of abiotic variables on ecosystem properties in the fen model, though SLA indirectly affected soil C through its negative association with leaf $\mathrm{C} / \mathrm{N}$ ratio (Fig. $4 \mathrm{a}$ ).

In the herb fen model (Fig. 4b), leaf traits and ecosystem properties showed moderate to large responses to changes in explanatory variables (see $r^{2}$ values in Fig. $4 \mathrm{~b}$ and coefficients in Table 4). Intensely managed sites
Table 1. Ellipses in panels a and c enclose all plots and species within management categories (coded $\mathrm{A}$ to $\mathrm{E}$ as in Table 1). A posteriori projection of abiotic variables (single-headed arrows in panels a and c) show the direction of the gradient for management and five-year water table height (WT5yr) in summer (S) and winter (W). The lengths of the arrows are proportional to the correlation between the variables and the ordination

were characterized by higher leaf $\mathrm{C} / \mathrm{N}$ ratio and live AGB, but lower SLA and dead AGB (Fig. 4b, Table 4). Changes in mean water table height in summer and winter were moderately associated with changes in leaf $\mathrm{C} / \mathrm{N}$ ratio and SLA (Fig. 4b, Table 4). Soil $\mathrm{C}$ increased under wetter conditions in winter, but drier summers were also associated with higher soil C (Fig. $4 \mathrm{~b}$, Table 4). Wetter summers and winters were associated with higher and lower dead AGB, respectively (Fig. 4b, Table 4). Despite the significant links between summer water table height and other variables in the herb fen model (Fig. 4b), the average position of the water table in summer was never above the surface (nor above the $10-\mathrm{cm}$ sampling horizon) in the herbaceous communities in Woodwalton during the five years before sampling (Fig. 5). Similar to the fen model (Fig. 4a), high leaf $\mathrm{C} / \mathrm{N}$ ratio and $\mathrm{LDMC}$ were associated with low SLA (Fig. 4b, Table 4). There were indirect effects of leaf $\mathrm{C} / \mathrm{N}$ ratio and SLA on dead AGB through their link with LDMC (Fig. 4b). 


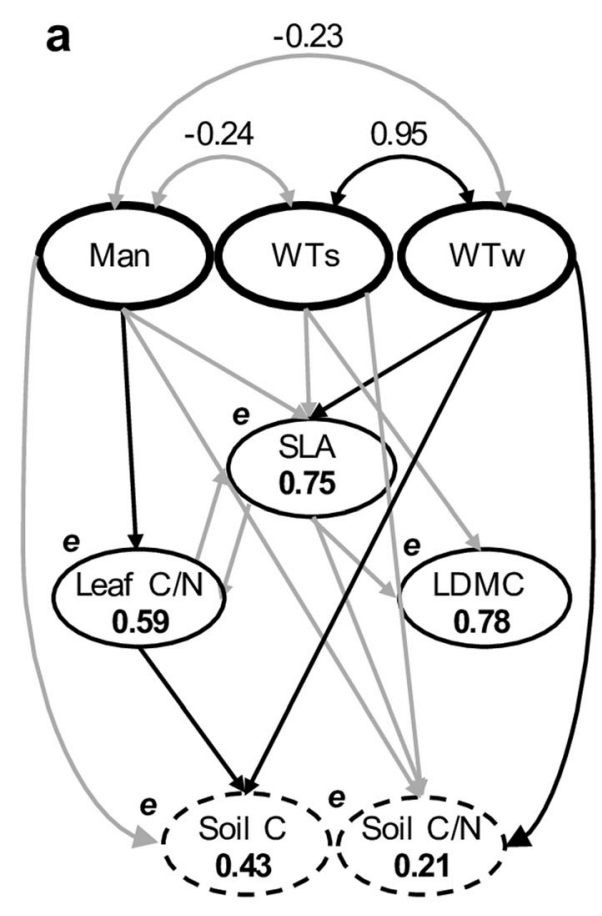

Fen model

Fig. 4 Path diagrams depicting direct and indirect effects of abiotic variables (bold ovals) and leaf traits (solid ovals) on ecosystem properties (dashed ovals). All sampling plots were considered together (fen model, panel a) and separately (herb fen model for herbaceous sites in Woodwalton only, panel b). Single-headed arrows show direct effects and denote standardized partial regression coefficients (all coefficients retained in the models are significant at $p<0.05$ ). Positive effects are shown by black lines and negative effects by grey lines. Double-headed arrows show

\section{Discussion}

Direct effects of abiotic variables on ecosystem properties

Soil $\mathrm{C}$ content, soil $\mathrm{C} / \mathrm{N}$ ratio and $\mathrm{AGB}$ responded strongly to the direct effects of abiotic variables. Lower soil $\mathrm{C}$ and soil $\mathrm{C} / \mathrm{N}$ ratio in frequently mown sites were probably due to the fact that cuttings were routinely removed from the herb fens after mowing, preventing organic matter from entering the soil. Environmental conditions in fens where mowing does not take place but are still subject to biomass removal through different management (e.g., grazing) may be more conducive to enhancing soil $\mathrm{C}$. The frequent summer mowing that takes place in some of our studied herbaceous sites results in significant and abrupt biomass loss during

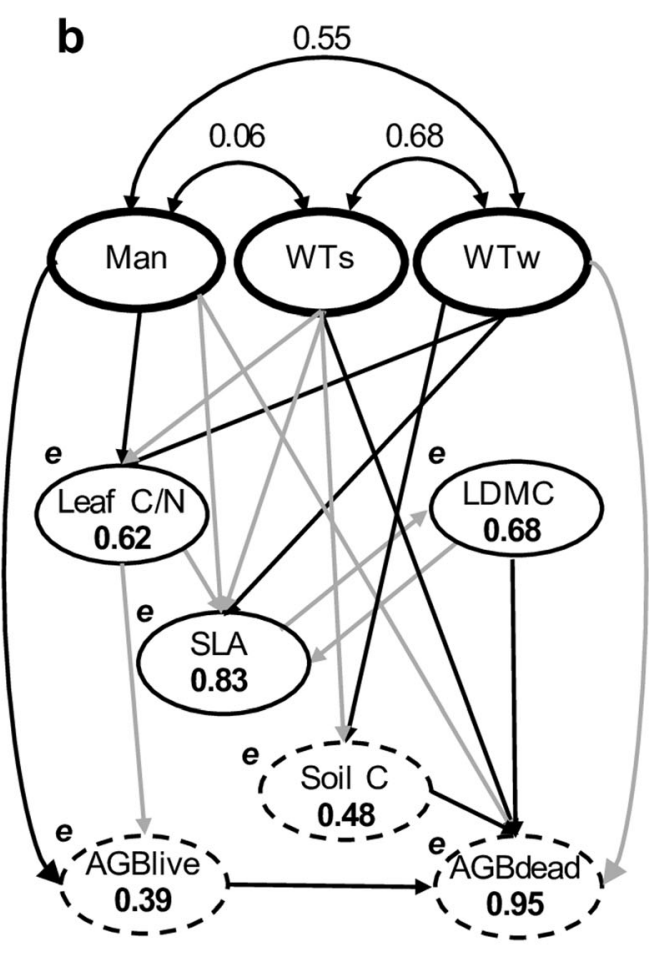

Herb fen model

correlations between independent variables (black lines for positive correlations and grey lines for negative correlations, with $r$ values shown on top of each double-headed arrow). Numbers in bold inside the ovals of dependent variables show the proportion of their variances $\left(r^{2}\right)$ explained by their predictor variables. Residual errors $(\boldsymbol{e})$ on the top left-hand-side of dependent variables represent unexplained variance. For an overview of the variables and their abbreviations see Table 2

the growing season, whereas moderate grazing causes constant but reduced biomass disturbance by foraging and trampling (Stammel et al. 2003). Moreover, cattle trampling in fen pastures can lead to the compaction of soft peat soils and promote wetter and more anoxic conditions (Whinam and Chilcott 1999) that may generally favor organic matter accumulation and soil $\mathrm{C}$. Grazing can also influence nutrient availability to plants (Schrautzer et al. 2013) that affect plant growth and vegetative biomass. For instance, previous studies have found significant differences in the grass/forb ratio between fen pastures and mown fens, with tiller-forming grasses more abundant on regularly grazed fen pastures (Bullock et al. 1994) and forbs more common in mown sites (Stammel et al. 2003). Similar changes in vegetation composition might happen after long-term abandonment of fens where tall sedge species may come to 
Table 4 Standardized partial regression coefficients between abiotic variables and leaf traits, abiotic variables and ecosystem properties, leaf traits and leaf traits, as well as leaf traits and ecosystem properties

\begin{tabular}{|c|c|c|c|c|c|c|c|c|c|c|c|c|c|c|}
\hline & \multicolumn{6}{|c|}{ Leaf traits } & \multicolumn{8}{|c|}{ Ecosystem properties } \\
\hline & \multicolumn{2}{|c|}{ Leaf $\mathrm{C} / \mathrm{N}$ ratio } & \multicolumn{2}{|l|}{ SLA } & \multicolumn{2}{|c|}{ LDMC } & \multicolumn{2}{|l|}{ Soil C } & \multicolumn{2}{|c|}{ Soil $\mathrm{C} / \mathrm{N}$ ratio } & \multicolumn{2}{|c|}{ Live AGB } & \multicolumn{2}{|c|}{ Dead AGB } \\
\hline & $a$ & $b$ & $a$ & $b$ & $a$ & $b$ & $a$ & $b$ & $a$ & $b$ & $a$ & $b$ & $a$ & $b$ \\
\hline Management & 0.55 & 0.31 & -0.44 & -0.33 & - & - & -0.49 & - & -0.5 & - & - & 0.83 & - & -0.58 \\
\hline WTs & - & -0.27 & -1.07 & -0.48 & -0.2 & - & - & -0.51 & -1.12 & - & - & - & - & 0.85 \\
\hline WTw & - & 0.69 & 0.55 & 0.48 & - & - & 0.42 & 0.93 & 0.5 & - & - & - & - & -0.87 \\
\hline Leaf $\mathrm{C} / \mathrm{N}$ ratio & - & - & -0.32 & -0.47 & - & - & 0.57 & - & - & - & - & -0.42 & - & - \\
\hline SLA & -0.26 & - & - & - & -0.95 & -0.67 & - & - & -0.53 & - & - & - & - & - \\
\hline LDMC & - & - & - & -0.4 & - & - & - & - & - & - & - & - & - & 0.1 \\
\hline
\end{tabular}

Variables down the rows on the left-hand side are predictor variables and those along the columns are response variables. All coefficients shown are significant at $p<0.05$. Coefficients $>0.8$ represent large effects, between 0.2 and 0.8 moderate effects and $<0.2$ small effects. See Table 2 for abbreviations

$a-$ Fen model (Fig. 4a)

$b-$ Herb fen model (Fig. 4b)

dominate (Diemer et al. 2001) and lead to a decrease in peat-forming moss species (Merriam et al. 2018) due to reduced light availability for prostrate plants (Mälson et al. 2008). The prevalence of thick-leaved monocots over soft-leaved forbs can alter the amount of carbon entering the soil due to changes in plant litter quality and quantity (see section below). Therefore, different landuses (e.g., pastureland, abandoned fens) can significantly alter biomass loss and accumulation rates in fens and affect not only vegetation composition but soil $\mathrm{C}$

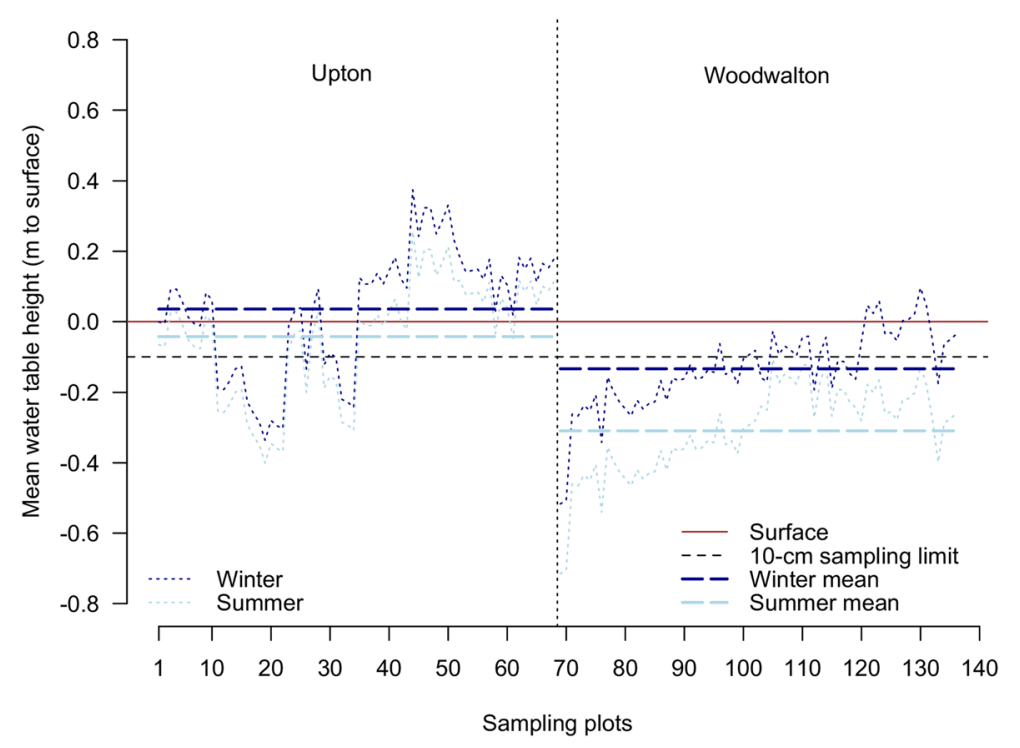

Fig. 5 Plot-level winter (dark blue dotted line) and summer (light blue dotted line) water table height in Upton and Woodwalton (left and right panels, respectively separated by dotted vertical line) averaged over the previous five years preceding soil sampling (2007-2012 for Upton and 2008-2013 for Woodwalton; see Table 2 for means and standard deviations). Horizontal solid brown line represents the surface level of sampling plots (standardized to zero) and horizontal dashed line shows the vertical limit of soil sampling (10 $\mathrm{cm}$ below surface). Horizontal large-dashed dark blue and light blue lines show the winter and summer means, respectively (see Table 2 for standard deviations) of Upton (left panel) and Woodwalton (right panel). Plot numbers (x axis) are as shown in Online Resource 1: Fig. S1.1 
content, especially in the top layer where most soil processes take place. Therefore, we caution against generalizing our results to fens where mowing and removal of cuttings are not common management practices.

Changes in soil saturation seem to have had a larger impact on soil nutrient content than management in our studied sites. In line with our expectation, the increase in soil $\mathrm{C}$ and soil $\mathrm{C} / \mathrm{N}$ ratio under wetter conditions in winter most likely indicate reduced decomposition of plant material under anaerobic conditions (Mitsch and Gosselink 2015), promoting the build-up of undecayed plant litter and enhanced soil $\mathrm{C}$ content in the top layer. However, contrary to our general expectation of wetter conditions enhancing soil $\mathrm{C}$ content, enhanced soil saturation in summer resulted in lower soil $\mathrm{C} / \mathrm{N}$ ratio in the fen model and lower soil $\mathrm{C}$ in the herb fen model. There are several alternative explanations for this result since soil saturation and temperature in summer can be highly correlated and changes in temperature may help explain changes in soil $\mathrm{C}$ content. Firstly, northern peatlands in the UK may take up more $\mathrm{CO}_{2}$ during summer than they release into the atmosphere due to increased net ecosystem productivity under higher temperatures (Bellisario et al. 1998). However, wetter conditions during warm periods may reduce rates of photosynthetic $\mathrm{C}$ fixation by the vegetation and result in reduced $\mathrm{C}$ uptake by wetland environments (Dušek et al. 2009). When the water level recedes, there can be an increase in $\mathrm{C}$ uptake by the vegetation, but also greater $\mathrm{C}$ losses via respiration due to enhanced aerobic decomposition (Dušek et al. 2009), with the outcome highly dependent on soil temperature (Updegraff et al. 2001), substrate density and quality (Bridgham et al. 1998), amount of evapotranspiration (Waddington and Price 2000) and the onset and severity of drought (Lund et al. 2012). Secondly, carbon uptake by peatlands can be negatively impacted during dry periods due to lower photosynthetic rates and biomass accumulation resulting from Sphagnum moss desiccation, which can turn peatlands into carbon sources rather than sinks (Lund et al. 2012). Thirdly, the timing of dry periods may also have a significant influence on soil $\mathrm{C}$ content in peatlands (Bellisario et al. 1998) since late summer droughts may coincide with increased plant senescence and soil aeration to intensify soil $\mathrm{C}$ loss due to higher nutrient mineralization. In addition, soil saturation in wetlands can be enhanced by the prevalence of mosses due to their intra- and extracellular water holding capacities and slow decomposition rates (Turetsky et al. 2008) that may depend on similar trade-offs in resource acquisition and conservation as seen for vascular plants (Mazziotta et al. 2019). As a consequence, mosses can contribute to waterlogging and anoxia and act as important peat-forming agents in fens (Stammel et al. 2003) that can enhance soil C build-up. Despite their relatively high abundance in the alder carr at Upton, mosses showed low percentage cover in Upton and Woodwalton compared to most peatlands and may have played a minor role in influencing soil saturation at these sites. Despite fens being potentially better buffered against the effects of drought due to groundwater input in addition to precipitation (Aurela et al. 2004), the five-year average position of the water table in summer in the herb fens in Woodwalton was never above the upper $10 \mathrm{~cm}$ of soil, meaning constant aeration of the top soil during warm months may have led to soil $\mathrm{C}$ loss regardless of changes in water table height. Therefore, anaerobic conditions in winter due to waterlogging and lower temperatures contributed to slower decomposition and were likely more important in influencing soil $\mathrm{C}$ content in our sites than the degree of soil saturation in summer (compare coefficients in Table 4).

Wetter conditions in summer and winter were associated with higher and lower dead AGB, respectively. Generally, drier conditions coupled with higher temperatures in summer may favor higher live biomass production through increased net ecosystem respiration as a result of an increased oxic zone positively impacting on plant growth and productivity (Bellisario et al. 1998). However, live and dead AGB may be better descriptors of changes in vegetation management in our sites than changes in soil saturation since AGB was highly dependent on the intensity of mowing. There was a buildup of dead biomass as a function of low management intervention in the Phragmites fen in Woodwalton (mowing intervals of approximately 20 years; Fig. 2i), where summer months were relatively wet. However, there was no dead biomass in the annually mown sedge fen in Woodwalton (Fig. 2i), where soil saturation in winter was the highest across the two fen sites. Regular mowing and removal of cuttings is seemingly maintaining early succession herb fens where reduced competition can lead to high net primary productivity of a few species (Graf and Rochefort 2009) that results in relatively high live AGB.

\section{Response and effect traits}

Our results confirm the close links between the traits of green leaves and abiotic variables and lend further support to the response-effect framework proposed by 
Lavorel and Garnier (2002). Leaf C/N ratio, SLA and LDMC showed significant responses to changing environmental conditions (management and soil saturation) and moderate direct effects on ecosystem properties driven by the trade-off between the conservation and acquisition of resources. As shown here and elsewhere (Minden and Kleyer 2011; Pakeman 2011), leaf C/N ratio and LDMC correlated negatively with SLA since leaves with high dry mass-to-area ratio tend to be thick and N-poor with long lifespans (Cornelissen et al. 2004). In contrast, species with soft leaves are normally characterized by high SLA, high leaf $\mathrm{N}$ and short leaf lifespans (Niinemets and Sack 2006). Species responses to different levels of disturbance may result in contrasting strategies that can have cascading effects on soil nutrient content and aboveground biomass.

Plant response traits may be particularly sensitive to vegetation management (Pakeman 2011; Pakeman and Marriott 2010). Increasing mowing intensity resulted in communities dominated by thick-leaved species with high LDMC and leaf C/N ratio and low SLA. Regular management of fens not only prevent the establishment of woody species but can favor rush-like plant communities that establish well in fen habitats (Carvalho 2017; Kołos and Banaszuk 2013). These communities tend to be dominated by fast-growing, thick-leaved tall monocotyledons with conservative economic strategies along the LES continuum (i.e., conservation of resources within wellprotected leaf tissue with extended durability and resistance to disturbance; e.g., Calamagrostis canescens, Cladium mariscus, Juncus subnodulosus, Molinia caerulea). Alternatively, the unmanaged wooded fens were dominated by thin-leaved deciduous woody species typified by exploitative strategies suitable for the rapid acquisition of resources due to leaves with relatively short lifespans (e.g., Alnus glutinosa, Fraxinus excelsior, Betula pubescens). Therefore, increasing mowing intensity promoted a significant shift in the mean leaf trait composition of fen plant communities, from acquisitive, soft-leaved species to conservative, thick-leaved plants. Annual mowing of wetland habitats seems to have broad similar effects in leading to the dominance of adventitious monocots (Kołos and Banaszuk 2018), but other confounding factors like climate, topography, the length and timing of mowing and the water regime may influence the shift in functional composition reported here (Kennedy et al. 2003; Zelnik and Čarni 2013).

The response of leaf traits to soil saturation in summer and winter were somewhat equivocal. Thin-leaved species with high SLA were associated with wetter conditions in winter, probably due to increased demand for nitrogen for osmoregulation under high groundwater levels (Minden and Kleyer 2011). However, wetter conditions in summer were related to low SLA. Reduced SLA can actually confer an advantage to flood-sensitive species in saturated soils to reduce evaporative loss under lower water uptake by roots with lower conductance in anoxic conditions (Poorter et al. 2009). However, tolerant fen species may have adaptations to waterlogged conditions that may lessen this effect (e.g., modified aerenchyma tissue in roots and shoots; Keddy 2010). Thick-leaved species with high leaf $\mathrm{C} / \mathrm{N}$ ratio and LDMC dominated under drier conditions in summer due to better conservation of resources within protective tissue (de Deyn et al. 2008). Paradoxically, wetter conditions in winter were also associated with higher leaf $\mathrm{C} / \mathrm{N}$ ratio. Leaf $\mathrm{N}$ may decrease because increasing soil saturation and oxygen depletion tend to result in lower $\mathrm{N}$ availability in soil due to higher $\mathrm{N}$ losses through denitrification (Ordoñez et al. 2010). Despite prolonged soil saturation broadly favoring conservative habits in wetland species (Moor et al. 2017), these results suggest that leaf trait responses to changing environmental conditions are not linear (e.g., BaastrupSpohr et al. 2015) and may indicate confounding effects of abiotic variables (e.g., management) or compensatory changes between traits (Moor et al. 2017).

Plant effect traits may overlap with response traits and help explain species' influence on ecosystem properties. Communities with high leaf $\mathrm{C} / \mathrm{N}$ ratio were characterized by relatively high soil C, while those with high SLA had low soil $\mathrm{C} / \mathrm{N}$ ratio. The effects of leaf traits on soil nutrient content reflect the quality of plant material entering the soil (Fortunel et al. 2009; Freschet et al. 2010; Grigulis et al. 2013). The change from soft-leaved (high SLA, low leaf $\mathrm{C} / \mathrm{N}$ ratio) to thick-leaved (low SLA, high leaf $\mathrm{C} / \mathrm{N}$ ratio) species along the management gradient indicates a shift from fast leaf litter decomposition and mineralization rates (Cornwell et al. 2008) to recalcitrant leaf litter conducive of organic matter build-up in soils (Cornelissen et al. 1999). Leaf litter richer in recalcitrant $C$ compounds (e.g., lignin) may enhance soil C (Cornelissen et al. 2004) due to reduced microbial activity (Wardle et al. 2004). Leaf litter quality may actually be more important in driving decomposition rates and soil nutrient content in peatlands than changes in soil saturation (Straková et al. 2012). However, routine removal of cuttings is preventing recalcitrant leaf litter produced by the mown communities 
from entering the soil, negatively impacting soil $\mathrm{C}$ content of the managed herb fens.

Leaf effect traits influenced not only soil properties in our models but also aboveground biomass in the herbaceous fens. Plant traits have been found to significantly affect aboveground primary productivity (Mokany et al. 2008), with increases in leaf $\mathrm{N}$ and photosynthetic capacity (normally associated with high SLA) resulting in faster nutrient cycling and thus increased biomass production through higher rates of organic matter mineralization and primary productivity (Lavorel and Grigulis 2012). Therefore, decreasing live AGB with increasing leaf $\mathrm{C} / \mathrm{N}$ ratio in our herb fen model was aligned with our hypothesis of conservative species being associated with lower biomass production. This was partly driven by the comparatively high SLA and low leaf C/N ratio of relatively common soft-leaved forbs in some of the herb fens (e.g., Galium uliginosum, Lotus pedunculatus, Mentha aquatica). The tendency of increasing dead AGB with increasing LDMC may be due to the dominance of thick-leaved monocotyledons (e.g., Calamagrostis canescens, Phragmites australis) in the unmown glades and in the Phragmites fen, where dead AGB accumulated due to low management intervention.

\section{Conclusions}

Our hypothesis of slow turnover rates in fen peatlands being driven by high intensity management that results in plant communities characterized by conservative strategies was generally confirmed. The models presented here provide a credible representation of the interactions between the ecosystem components of the lowland fens studied, particularly given the robust model results. It helps to answer important questions related to the relative effect sizes of plant traits and abiotic variables on ecosystem processes in wetlands (Moor et al. 2017). Despite the significant links between leaf traits and ecosystem properties, abiotic variables accounted for some of the largest direct effects on changes in soil nutrients and plant biomass. The mapping of some common leaf traits (e.g., SLA, LDMC) to ecosystem functioning may be affected by low variability in leaf lifespan (LLS; not measured here) between cooccurring species within a community since LLS influences differences among species in resource acquisition (e.g., fast vs. slow carbon gain; Funk and Cornwell 2013). However, the largest direct effect on soil $C$ when considering all communities in combination (fen model) was that of leaf $\mathrm{C} / \mathrm{N}$ ratio (Table 4), suggesting our study captured enough trait variability between plant communities with contrasting strategies (conservation of resources and resistance to disturbance vs. fast acquisition of resources for rapid growth) to reveal important links between leaf traits and ecosystem properties.

These results have wider implications for the conservation of lowland fens. Management practices that include mowing at varying intensities and the rewetting of drained fens (e.g., Gauci 2008) may interact to affect soil nutrients (Schrautzer et al. 2013) and aboveground biomass (Fossati and Pautou 1989) of fen peatlands. Mowing and removal of cuttings may reduce plant litter deposition and negatively affect soil $\mathrm{C}$ content, but the accumulation of biomass in unmown fens may result in a reduction of peat-forming mosses due to reduced ground light availability for prostrate plants (Merriam et al. 2018). It can also be detrimental to rare fen species (Middleton et al. 2006). Management practices must thus be carefully considered to avoid excessive biomass accumulation of fens on one hand and the negative impact on soil properties on the other.

Acknowledgements We thank Alan Bowley and Craig Bellwood at Natural England and Debs Kershaw at the Norfolk Wildlife Trust for access to Woodwalton Fen and Upton Broad, respectively and information about the sites. We are also grateful to the Environment Agency for providing dipwell data for Upton Broad. FC was funded through a PhD studentship from the Faculty of Sciences, Engineering and Computing at Kingston University London. Field work and laboratory analyses were supported by the Department of Geography and Geology at Kingston University London.

\section{Compliance with ethical standards}

Conflict of interest The authors declare that they have no conflict of interest.

Open Access This article is distributed under the terms of the Creative Commons Attribution 4.0 International License (http:// creativecommons.org/licenses/by/4.0/), which permits unrestricted use, distribution, and reproduction in any medium, provided you give appropriate credit to the original author(s) and the source, provide a link to the Creative Commons license, and indicate if changes were made.

\section{References}

Aurela M, Laurila T, Tuovinen J-P (2004) The timing of snow melt controls the annual $\mathrm{CO} 2$ balance in a subarctic fen. Geophys Res Lett 31:L16119. https://doi.org/10.1029/2004GL020315 
Baastrup-Spohr L, Sand-Jensen K, Nicolajsen SV, Bruun HH (2015) From soaking wet to bone dry: predicting plant community composition along a steep hydrological gradient. J Veg Sci 26:619-630. https://doi.org/10.1111/jvs.12280

Bellisario LM, Moore TR, Bubier JL (1998) Net ecosystem $\mathrm{CO}_{2}$ exchange in a boreal peatland, northern. Manitoba. Écoscience 5:517-525. https://doi.org/10.1080 /11956860.1998.11682491

Bennion H, Appleby PG, Phillips GL (2001) Reconstructing nutrient histories in the Norfolk broads, UK: implications for the role of diatom-total phosphorus transfer functions in shallow lake management. J Paleolimnol 26:181-204. https://doi.org/10.1023/a:1011137625746

Borcard D, Gillet F, Legendre P (2011) Numerical ecology with R. use R! Springer, New York. https://doi.org/10.1007/978-14419-7976-6

Bridgham SD, Updegraff K, Pastor J (1998) Carbon, nitrogen, and phosphorus mineralization in northern wetlands. Ecology 79: $1545-1561$. https://doi.org/10.1890/00129658(1998)079[1545:CNAPMI]2.0.CO;2

Browne M, Cudeck R (1993) Alternative ways of assessing equation model fit. In: LJ S (ed) Boollen KA. Testing structural equation models. SAGE Publications, Newbury Park, CA, USA, pp 136-162

Bullock JM, Hill BC, Silvertown J (1994) Tiller dynamics of two grasses-responses to grazing, density and weather. J Ecol 82: 331-340. https://doi.org/10.2307/2261301

Byrne BM (2010) Structural equation modeling with AMOS: basic concepts, applications, and programming, 2nd edn. Routledge Taylor \& Francis Group, New York, NY

Carvalho F (2017) Using plant functional traits to assess ecosystem processes and community dynamics in lowland fens: understanding the efficacy and applicability of a trait-based approach to plant ecology. PhD Thesis, Kingston University London. Available at http://ethos.bl.uk/OrderDetails. do?uin=uk.bl.ethos.718639. Accessed 15 February 2019

Charman D (2002) Peatlands and Environmental Change. Wiley, Chichester, UK

Cornelissen JHC et al (1999) Leaf structure and defence control litter decomposition rate across species and life forms in regional floras on two continents. New Phytol 143:191200. https://doi.org/10.1046/j.1469-8137.1999.00430.x

Cornelissen JHC et al (2004) Leaf digestibility and litter decomposability are related in a wide range of subarctic plant species and types. Funct Ecol 18:779-786. https://doi. org/10.1111/j.0269-8463.2004.00900.x

Cornwell WK, Cornelissen JHC, Amatangelo K, Dorrepaal E, Eviner VT, Godoy O, Hobbie SE, Hoorens B, Kurokawa H, Pérez-Harguindeguy N, Quested HM, Santiago LS, Wardle DA, Wright IJ, Aerts R, Allison SD, van Bodegom P, Brovkin V, Chatain A, Callaghan TV, Díaz S, Garnier E, Gurvich DE, Kazakou E, Klein JA, Read J, Reich PB, Soudzilovskaia NA, Vaieretti MV, Westoby M (2008) Plant species traits are the predominant control on litter decomposition rates within biomes worldwide. Ecol Lett 11:10651071. https://doi.org/10.1111/j.1461-0248.2008.01219.x

Dainese M, Leps J, de Bello F (2015) Different effects of elevation, habitat fragmentation and grazing management on the functional, phylogenetic and taxonomic structure of mountain grasslands. Perspect Plant Ecol 17:44-53. https://doi. org/10.1016/j.ppees.2014.09.002 de Deyn GB, Cornelissen JHC, Bardgett RD (2008) Plant functional traits and soil carbon sequestration in contrasting biomes. Ecol Lett 11:516-531. https://doi.org/10.1111/j.14610248.2008.01164.x

Diemer M, Oetiker K, Billeter R (2001) Abandonment alters community composition and canopy structure of Swiss calcareous fens. Appl Veg Sci 4:237-246. https://doi. org/10.1111/j.1654-109X.2001.tb00492.x

Donovan LA, Mason CM, Bowsher AW, Goolsby EW, Ishibashi CDA (2014) Ecological and evolutionary lability of plant traits affecting carbon and nutrient cycling. J Ecol 102:302314. https://doi.org/10.1111/1365-2745.12193

Dušek J, Čížková H, Czerný R, Taufarová K, Šmídová M, Janouš D (2009) Influence of summer flood on the net ecosystem exchange of $\mathrm{CO} 2$ in a temperate sedge-grass marsh. Agric For Meteorol 149:1524-1530. https://doi.org/10.1016/j. agrformet.2009.04.007

Fortunel C, Garnier E, Joffre R, Kazakou E, Quested H, Grigulis $\mathrm{K}$, Lavorel S, Ansquer P, Castro H, Cruz P, Doležal J, Eriksson O, Freitas H, Golodets C, Jouany C, Kigel J, Kleyer M, Lehsten V, Lepš J, Meier T, Pakeman R, Papadimitriou M, Papanastasis VP, Quétier F, Robson M, Sternberg M, Theau JP, Thébault A, Zarovali M (2009) Leaf traits capture the effects of land use changes and climate on litter decomposability of grasslands across. Europe. Ecology 90:598-611

Fossati J, Pautou G (1989) Vegetation dynamics in the fens of Chautagne (Savoie, France) after the cessation of mowing. Vegetatio 85:71-81. https://doi.org/10.1007/bf00042257

Freschet GT, Cornelissen JHC, Van Logtestijn RSP, Aerts R (2010) Evidence of the 'plant economics spectrum' in a subarctic flora. J Ecol 98:362-373. https://doi.org/10.1111 j.1365-2745.2009.01615.x

Funk JL, Cornwell WK (2013) Leaf traits within communities: context may affect the mapping of traits to function. Ecology 94:1893-1897. https://doi.org/10.1890/12-1602.1

Garnier E, Navas ML, Grigulis K (2016) Plant functional diversity: organism traits, community structure, and ecosystem properties. Oxford University Press, Oxford

Gauci V (2008) Carbon balance and offset potential of the great fen project. The Open University and GLCC,

Grace JB, Pugesek BH (1997) A structural equation model of plant species richness and its application to a coastal wetland. Am Nat 149:436-460

Graf M, Rochefort L (2009) Examining the peat-accumulating potential of fen vegetation in the context of fen restoration of harvested peatlands. Écoscience 16:158-166. https://doi. org/10.2980/16-2-3128

Grigulis K, Lavorel S, Krainer U, Legay N, Baxendale C, Dumont M, Kastl E, Arnoldi C, Bardgett RD, Poly F, Pommier T, Schloter M, Tappeiner U, Bahn M, Clément JC (2013) Relative contributions of plant traits and soil microbial properties to mountain grassland ecosystem services. J Ecol 101: 47-57. https://doi.org/10.1111/1365-2745.12014

Keddy PA (2010) Wetland ecology: principles and conservation, 2nd edn. Cambridge University Press, New York

Kennedy MP, Milne JM, Murphy KJ (2003) Experimental growth responses to groundwater level variation and competition in five British wetland plant species. Wetl Ecol Manag 11:383-396. https://doi.org/10.1023 /B:WETL.0000007194.01073.6b 
Kołos A, Banaszuk P (2013) Mowing as a tool for wet meadows restoration: effect of long-term management on species richness and composition of sedge-dominated wetland. Ecol Eng 55:23-28. https://doi.org/10.1016/j.ecoleng.2013.02.008

Kołos A, Banaszuk P (2018) Mowing may bring about vegetation change, but its effect is strongly modified by hydrological factors. Wetl Ecol Manag 26:879-892. https://doi. org/10.1007/s11273-018-9615-X

Lavorel S, Garnier E (2002) Predicting changes in community composition and ecosystem functioning from plant traits: revisiting the holy grail. Funct Ecol 16:545-556. https://doi. org/10.1046/j.1365-2435.2002.00664.x

Lavorel S, Grigulis K (2012) How fundamental plant functional trait relationships scale-up to trade-offs and synergies in ecosystem services. J Ecol 100:128-140. https://doi. org/10.1111/j.1365-2745.2011.01914.x

Lund M, Christensen TR, Lindroth A, Schubert P (2012) Effects of drought conditions on the carbon dioxide dynamics in a temperate peatland. Environ Res Lett 7:045704. https://doi. org/10.1088/1748-9326/7/4/045704

Mainstone C, Hall R, Diack I (2016) A narrative for conserving freshwater and wetland habitats in England vol 064. Natural England Research Report NERR 064, Peterborough, UK

Mälson K, Backéus I, Rydin H (2008) Long-term effects of drainage and initial effects of hydrological restoration on rich fen vegetation. Appl Veg Sci 11:99-106. https://doi. org/10.1111/j.1654-109X.2008.tb00208.x

Maruyama G (1998) Basics of structural equation modeling. SAGE Publications, Inc, Thousand Oaks, California

Mazziotta A, Granath G, Rydin H, Bengtsson F, Norberg J (2019) Scaling functional traits to ecosystem processes: towards a mechanistic understanding in peat mosses. J Ecol 107:843859. https://doi.org/10.1111/1365-2745.13110

Merriam KE, Markwith SH, Coppoletta M (2018) Livestock exclusion alters plant species composition in fen meadows. Appl Veg Sci 21:3-11. https://doi.org/10.1111/avsc.12333

Middleton BA, Holsten B, van Diggelen R (2006) Biodiversity management of fens and fen meadows by grazing, cutting and burning. Appl Veg Sci 9:307-316. https://doi. org/10.1111/j.1654-109X.2006.tb00680.x

Minden V, Kleyer M (2011) Testing the effect-response framework: key response and effect traits determining aboveground biomass of salt marshes. J Veg Sci 22:387-401. https://doi.org/10.1111/j.1654-1103.2011.01272.x

Minden V, Scherber C, Cebrián Piqueras MA, Trinogga J, Trenkamp A, Mantilla-Contreras J, Lienin P, Kleyer M (2016) Consistent drivers of plant biodiversity across managed ecosystems. Philosophical Transactions of the Royal Society of London B: Biological Sciences 371:20150284. https://doi.org/10.1098/rstb.2015.0284

Mitsch WJ, Gosselink JG (2015) Wetlands, 5th edn. John Wiley and Sons, Inc, Hoboken, NJ

Mokany K, Ash J, Roxburgh S (2008) Functional identity is more important than diversity in influencing ecosystem processes in a temperate native grassland. J Ecol 96:884-893. https://doi.org/10.1111/j.1365-2745.2008.01395.x

Moor H, Rydin H, Hylander K, Nilsson MB, Lindborg R, Norberg $\mathrm{J}$ (2017) Towards a trait-based ecology of wetland vegetation. J Ecol 105:1623-1635. https://doi.org/10.1111/13652745.12734
Morris PJ, Belyea LR, Baird AJ (2011) Ecohydrological feedbacks in peatland development: a theoretical modelling study. J Ecol 99:1190-1201. https://doi.org/10.1111/j.13652745.2011.01842.x

Musarika S, Atherton CE, Gomersall T, Wells MJ, Kaduk J, Cumming AMJ, Page SE, Oechel WC, Zona D (2017) Effect of water table management and elevated $\mathrm{CO}_{2}$ on radish productivity and on $\mathrm{CH}_{4}$ and $\mathrm{CO}_{2}$ fluxes from peatlands converted to agriculture. Sci Total Environ 584:665-672. https://doi.org/10.1016/j.scitotenv.2017.01.094

Niinemets Ü (1999) Research review. Components of leaf dry mass per area - thickness and density - alter leaf photosynthetic capacity in reverse directions in woody plants. New Phytol 144:35-47. https://doi.org/10.1046/j.14698137.1999.00466.x

Niinemets Ü, Sack L (2006) Structural determinants of leaf lightharvesting capacity and photosynthetic potentials. In: Esser K, Lüttge U, Beyschlag W, Murata J (eds) Progress in botany, vol 67. Springer Berlin Heidelberg, Berlin, Heidelberg, pp 385-419. https://doi.org/10.1007/3-540-27998-9_17

Oksanen J et al. (2019) Vegan: community ecology package. R package version 2.5-4, https://cran.r-project.org/package= vegan. Accessed 10 March 2019

Ordoñez JC, van Bodegom PM, Witte JPM, Bartholomeus RP, van Hal JR, Aerts R (2010) Plant strategies in relation to resource supply in Mesic to wet environments: does theory mirror nature? Am Nat 175:225-239. https://doi.org/10.1086 1649582

Pakeman RJ (2011) Multivariate identification of plant functional response and effect traits in an agricultural landscape. Ecology 92:1353-1365. https://doi.org/10.1890/10-1728.1

Pakeman RJ, Marriott CA (2010) A functional assessment of the response of grassland vegetation to reduced grazing and abandonment. J Veg Sci 21:683-694. https://doi. org/10.1111/j.1654-1103.2010.01176.x

Pérez-Harguindeguy N, Díaz S, Garnier E, Lavorel S, Poorter H, Jaureguiberry P, Bret-Harte MS, Cornwell WK, Craine JM, Gurvich DE, Urcelay C, Veneklaas EJ, Reich PB, Poorter L, Wright IJ, Ray P, Enrico L, Pausas JG, de Vos AC, Buchmann N, Funes G, Quétier F, Hodgson JG, Thompson K, Morgan HD, ter Steege H, Sack L, Blonder B, Poschlod P, Vaieretti MV, Conti G, Staver AC, Aquino S, Cornelissen JHC (2013) New handbook for standardised measurement of plant functional traits worldwide. Aust J Bot 61:167-234. https://doi.org/10.1071/Bt12225

Poorter H, Niinemets Ü, Poorter L, Wright IJ, Villar R (2009) Causes and consequences of variation in leaf mass per area (LMA): a meta-analysis. New Phytol 182:565-588. https://doi.org/10.1111/j.1469-8137.2009.02830.x

R Development Core Team (2018) R: a language and environment for statistical computing, 3.5.2 edn. R Foundation for Statistical Computing, Vienna, Austria

Schrautzer J, Sival F, Breuer M, Runhaar H, Fichtner A (2013) Characterizing and evaluating successional pathways of fen degradation and restoration. Ecol Indic 25:108-120. https://doi.org/10.1016/j.ecolind.2012.08.018

Schumacker RE, Lomax RG (2010) A beginner's guide to structural equation modeling. 3rd edn. Routledge, New York

Sokal RR, RohlfFJ (2012) Biometry: the principles and practice of statistics in biological research. 4th edn. W. H. Freeman and Company, New York 
Stammel B, Kiehl K, Pfadenhauer J (2003) Alternative management on fens: response of vegetation to grazing and mowing. Appl Veg Sci 6:245-254. https://doi.org/10.1111/j.1654-109 X.2003.tb00585.x

Straková P, Penttilä T, Laine J, Laiho R (2012) Disentangling direct and indirect effects of water table drawdown on above- and belowground plant litter decomposition: consequences for accumulation of organic matter in boreal peatlands. Glob Chang Biol 18:322-335. https://doi. org/10.1111/j.1365-2486.2011.02503.x

Turetsky MR, Crow SE, Evans RJ, Vitt DH, Wieder RK (2008) Trade-offs in resource allocation among moss species control decomposition in boreal peatlands. J Ecol 96:1297-1305. https://doi.org/10.1111/j.1365-2745.2008.01438.x

Updegraff K, Bridgham SD, Pastor J, Weishampel P, Harth C (2001) Response of $\mathrm{CO}_{2}$ and $\mathrm{CH}_{4}$ emissions from peatlands to warming and water table manipulation. Ecol Appl 11:311326. https://doi.org/10.2307/3060891

Vinther E, Hald AB (2000) Restoration of an abandoned speciesrich fen-meadow in Denmark: changes in species richness and dynamics of plant groups during 12 years. Nord J Bot 20: 573-584. https://doi.org/10.1111/j.1756-1051.2000.tb01608. $\mathrm{X}$

Violle C, Navas ML, Vile D, Kazakou E, Fortunel C, Hummel I, Garnier E (2007) Let the concept of trait be functional! Oikos 116:882-892. https://doi.org/10.1111/j.2007.00301299.15559.x

Waddington JM, Price JS (2000) Effect of peatland drainage, harvesting, and restoration on atmospheric water and carbon exchange. Phys Geogr 21:433-451. https://doi.org/10.1080 /02723646.2000.10642719

Waller M, Carvalho F, Grant MJ, Bunting MJ, Brown K (2017) Disentangling the pollen signal from fen systems: modern and Holocene studies from southern and eastern England. Rev Palaeobot Palynol 238:15-33. https://doi.org/10.1016/j. revpalbo.2016.11.007

Ward SE, Bardgett RD, McNamara NP, Ostle NJ (2009) Plant functional group identity influences short-term peatland ecosystem carbon flux: evidence from a plant removal experiment. Funct Ecol 23:454-462. https://doi.org/10.1111 /j.1365-2435.2008.01521.x
Wardle DA, Bardgett RD, Klironomos JN, Setälä H, van der Putten WH, Wall DH (2004) Ecological linkages between aboveground and belowground biota. Science 304:16291633

Westoby M, Falster DS, Moles AT, Vesk PA, Wright IJ (2002) Plant ecological strategies: some leading dimensions of variation between species. Annu Rev Ecol Syst 33:125-159. https://doi.org/10.1146/annurev.ecolsys.33.010802.150452

Wheeler BD, Proctor MCF (2000) Ecological gradients, subdivisions and terminology of north-west European mires. J Ecol 88:187-203. https://doi.org/10.1046/j.13652745.2000.00455.x

Wheeler BD, Shaw SC (1995) A focus on fens - controls on the composition of fen vegetation in relation to restoration. In: Wheeler BD, Shaw SC, Fojt WJ, Robertson RA (eds) Restoration of temperate wetlands. John Wiley \& Sons Ltd, Chichester, UK, pp 49-72

Whinam J, Chilcott N (1999) Impacts of trampling on alpine environments in Central Tasmania. J Environ Manag 57: 205-220. https://doi.org/10.1006/jema.1999.0302

Worrall F, Chapman P, Holden J, Evans C, Artz R, Smith P, Grayson R (2011) A review of current evidence on carbon fluxes and greenhouse gas emissions from UK peatland. JNCC Report, No. 442, Peterborough, UK

Wright IJ, Reich PB, Westoby M, Ackerly DD, Baruch Z, Bongers F, Cavender-Bares J, Chapin T, Cornelissen JHC, Diemer M, Flexas J, Garnier E, Groom PK, Gulias J, Hikosaka K, Lamont BB, Lee T, Lee W, Lusk C, Midgley JJ, Navas ML, Niinemets Ü, Oleksyn J, Osada N, Poorter H, Poot P, Prior L, Pyankov VI, Roumet C, Thomas SC, Tjoelker MG, Veneklaas EJ, Villar R (2004) The worldwide leaf economics spectrum. Nature 428:821-827. https://doi.org/10.1038 /nature 02403

Zelnik I, Čarni A (2013) Plant species diversity and composition of wet grasslands in relation to environmental factors. Biodivers Conserv 22:2179-2192. https://doi.org/10.1007 /s10531-013-0448-x

Publisher's note Springer Nature remains neutral with regard to jurisdictional claims in published maps and institutional affiliations. 